\title{
IDENTIFIKASI DAN PENGENDALIAN FAKTOR RISIKO MUKOSITIS ORAL SELAMA RADIOTERAPI KANKER NASOFARING ( Laporan Kasus )
}

\author{
Irna Sufiawati *, Gus Permana Subita** \\ * Resident in Department of Oral Medicine, Faculty of Dentistry, University of Indonesia \\ ** Academic Staff in Department of Oral Medicine, Faculty of Dentistry, University of Indonesia \\ Jl. Salemba Raya No.4, Jakarta Pusat. Telp. (021) 2303257
}

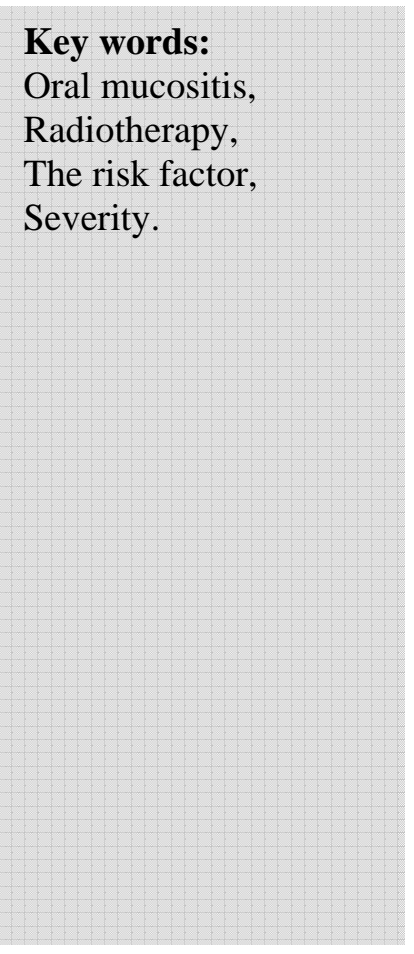

\begin{abstract}
Oral mucositis (OM) is an inflammatory and ulcerative process of the mucosa of the mouth that result from the administration of radiotherapy and/or chemotherapy or blood and marrow stem cell transplant. The incidence and severity of $\mathrm{OM}$ will vary from patient to patient, that correlates with the risk factors. The risk factors are patient related factors and therapy related factors. We reported a case in a 33 years old woman patient with OM grade IV accompanied with oral candidiasis who is undergoing radiotherapy in Cipto Mangunkusumo Hospital for her nasopharyngeal cancer. The estimated risk factors of the severity OM in this case are the patient gender, poor oral hygiene, poor nutritional status, decreased saliva production, dose total and fractional radiation, and the staging of cancer. Chlorhexidine gluconate $0.2 \%$ mouthwash and Mycostatin oral supension administration was decreased the severity of OM in this patient, nevertheless not yet totally recovery because another risk factors that can affect $\mathrm{OM}$ and dental management can not optimally controlled. It's concluded that identification and control of oral mucositis risk factors are required for minimize severity of OM, to achieve the better quality of life patient
\end{abstract}

\section{Pendahuluan}

Istilah mukositis oral muncul pada akhir tahun 1980, ${ }^{1,2,3}$ untuk menggambarkan proses inflamasi dan ulseratif pada mukosa orofaringeal yang diinduksi oleh kemoterapi dan/atau radioterapi, ${ }^{2-7}$ atau transplantasi darah dan sel stem sumsum tulang. ${ }^{8-10}$ Mukositis oral 
dapat mempengaruhi kualitas hidup pasien, $1,3,4,8,11-14$ meningkatkan risiko infeksi, ${ }^{2,5,8,9,13-15}$ menyebabkan penundaan/ interupsi bahkan kegagalan perawatan kanker itu sendiri, ${ }^{2-4,8,9,13-15}$ dan berakibat perlunya hospitalisasi serta meningkatnya biaya perawatan. $^{3,4,8,9,12,14}$ Insidensi mukositis oral diperkirakan $40 \%$ pada pasien yang menerima kemoterapi, ${ }^{1-4,9,15-17} 70 \%-90 \%$ pada pasien yang menjalani transplantasi darah dan sel stem sumsum tulang, ${ }^{1-4,16,18}$ dan $80 \%-100 \%$ pada pasien yang menjalani terapi radiasi yang melibatkan daerah oro-faring., ${ }^{1,3,4,9,11,13,16}$

Pada penatalaksanaan mukositis oral, penting untuk menilai derajat keparahannya, umumnya digunakan sistem penyekoran World Health Organization (WHO) 1979, ${ }^{1-4,12,16,18}$ dan sistem penyekoran National Cancer InstituteCommon Toxicity Criteria (NCI-CTC). ${ }^{1-5,9}$ Karena adanya kelemahan yang dirasakan dari sistem penilaian derajat mukositis oral yang ada, di tahun 2004 telah ditetapkan sistem penyekoran internasional baru yang disebut the Oral Mucositis Assesment Scale (OMS). ${ }^{4,9,12}$

Jika membicarakan tentang efek samping dari terapi kanker, meninjau faktor-faktor risiko adalah penting sehingga tenaga kesehatan dapat mengidentifikasi pasien mana yang berisiko, kenapa mereka berisiko, dan bagaimana cara terbaik mengurangi risiko tersebut. ${ }^{4}$ Kami mencoba membahas identifikasi dan pengendalian faktor risiko terjadinya mukositis oral pada seorang wanita dengan kanker nasofaring yang sedang menjalani radioterapi, sehingga dapat mengurangi keparahan mukositis oral tersebut dengan melakukan pena tala- ksanaan yang tepat, sehingga dapat mencapai kualitas hidup pasien yang lebih baik.

\section{Laporan Kasus}

Pada tanggal 26 September 2005, seorang pasien wanita berusia 33 tahun, berat badan $49 \mathrm{~kg}$ dan tinggi badan $155 \mathrm{~cm}$, datang ke poli Penyakit Mulut RSUPN Cipto Mangunkusumo dirujuk dari poli THT dengan diagnosis kerja karsinoma nasofaring (KNF) pro stagging untuk evaluasi dan tata laksana gigi-mulut. Riwayat penyakit
KNF diawali sejak 3 tahun yang lalu timbul benjolan di leher kiri, mulanya sebesar jempol tangan lalu semakin membesar. Sekitar 2 tahun yang lalu datang ke puskesmas diduga tuberkulosis kelenjar, berobat selama 3 bulan tetapi kemudian berhenti. Sejak 4 bulan yang lalu pasien berobat ke bedah tumor RSUPN-CM dan dikonsul ke poli THT untuk evaluasi dan tata laksana lebih lanjut. Kesimpulan masalah meliputi KNF derajat keganasan tinggi, keadaan umum lemah, intake makan sulit, anemia e.c perdarahan, dan leukositosis e.c tumor dengan infeksi sekunder. Pengobatan yang diterimanya berupa ceftriakson 1x2 gram, metronidazole drip 3x500 mg, metronidazole bubuk (tabur pada luka), parasetamol 3x500 mg dan Milanta syr 2xcth1 dan pemasangan naso-gaster tube (NGT). Pasien juga menderita hipertensi dan gangguan lambung kronis. Pasien telah diterapi radiasi eksterna 5 x 300 cGy (rencana 10 kali) sito untuk menghentikan perdarahan. dari masa tumor. Pasien mengeluh lidah, gigi geligi dan tenggorokan sakit sejak 2 hari yang lalu.

Keadaan umum pasien terlihat lemah, tetapi cukup kooperatif dan komunikatif. Pada pemeriksaan ekstra oral dijumpai kelenjar limfe submandibula kanan teraba, kenyal, tidak sakit, dan kelenjar submandibula kiri tidak dapat diraba. Pada leher kiri terdapat masa yang ditutupi kain kasa (dari catatan medik diketahui masa berukuran 8x8x6 cm, ulkus positif, pus positif). Bibir kering, deskuamasi dan fisur pada sudut bibir. Pada pemeriksaan intra oral dijumpai kebersihan mulut buruk,disertai perada ngan margin gingiva menyeluruh. Permukaan dorsal lidah tampak erosi dangkal dan bagian tengah tertutup lapisan putih kekuningan tebal yang dapat diangkat dengan meninggalkan dasar eritema (gambar 1a), pada lateral kanankiri lidah terdapat plak putih yang sulit diangkat dari anterior sampai pangkal lidah. Mukosa bukal kanan tampak erosi dangkal dan ditutupi bercak-bercak putih, menyebar, sebagian sulit diangkat dan sebagian dapat diangkat dengan meninggalkan dasar eritema (gambar 1b). Mukosa bukal kiri juga tampak erosi dangkal, terdapat plak putih kekuningan sepanjang garis oklusal pada regio gigi kaninus kiri sampai molar ketiga kiri, terutama regio molar ketiga 
yang sulit diangkat (gambar 1c). Palatum durum dan molle terdapat plak putih tipis pada regio posterior kiri dan kanan yang sulit diangkat. Pada pemeriksaan gigi geligi ditemukan gigi 3.8 karies mencapai pulpa non vital, gigi 3.7, 4.7, 4.8 karies email, dan gigi anterior rahang bawah berjejal. Secara visual, saliva tampak sedikit dan kental.

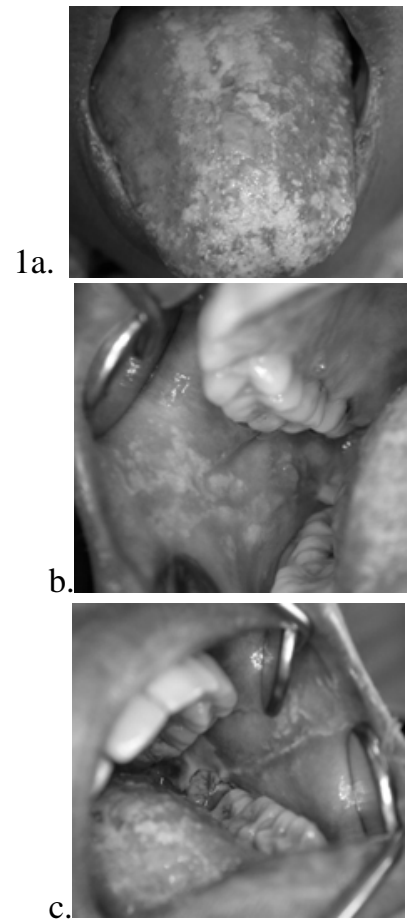

Gambar 1. Gambaran mukosa oral yang erosi, dangkal, sebagian tertutup lapisan putih kekuningan tebal yang dapat diangkat dengan meninggalkan dasar eritema dan sebagian tidak dapat diangkat. (a. dorsum lidah, b.mukosa bukal kanan, c. mukosa bukal kiri)

Pasien dikonsul ke poli kulit-kelamin untuk pemeriksaan mikologi langsung pada dorsum lidah dan mukosa bukal, dan hasilnya ditemukan blastospora dan pseudohifa positif tiga. Hasil pemeriksaan hematologi tanggal 22 September 2005 yaitu kadar Hb 10,4 g/dl, Ht 32,5\%, eritrosit 3,87 juta/ $\mu \mathrm{l}$, MCV $84 \mathrm{fl}, \mathrm{MCH}$ $27 \mathrm{pg}, \mathrm{MCHC} 32 \mathrm{~g} / \mathrm{dl}$, trombosit $489.000 \mu \mathrm{l}$, leukosit $7.100 \mu \mathrm{l}$, menunjukkan kesan bahwa pasien ini menderita anemia.

Berdasarkan hasil pemeriksaan di atas, dibuat diagnosis kerja yaitu mukositis oral derajat II e.c radioterapi disertai kandidiasis oral (kandidiasis pseudomembran dan keilitis angularis), Gingivitis Marginalis Kronis Generalisata, 3.8 Nekrosis Pulpa, gigi 3.7, 4.7, 4.8 Iritasio Pulpa. Pasien diresepkan obat kumur yang mengandung klorheksidin glukonat 0,2 \% untuk diseka dengan menggunakan kassa steril ke seluruh mukosa mulut dan gigi geligi, dan Mycostatin oral suspension 2 botol ( $1 \mathrm{ml}$ 4x/hari), serta Boor lanolin 25 gram (obat oles bibir) untuk mengatasi deskuamasi bibir. Untuk perbaikan kondisi intra oral dan menghilangkan fokus infeksi, direncanakan tindakan pembersihan karang gigi, pencabutan 3.8, dan penambalan 3.7, 4.7, 4.8. Mengingat kondisi pasien belum memungkinkan dan sedang dilakukan radioterapi maka tindakan dental ditunda terlebih dahulu.

Dua hari kemudian pasien datang untuk kontrol, rasa sakit di rongga mulut sudah berkurang. Pasien kurang teratur memakai obat yang diberikan karena merasa tidak nyaman, obat oles bibir tidak dipakai karena baunya tidak enak sehingga pasien mengoleskan madu pada bibirnya yang kering. Pada pemeriksaan klinis tidak tampak perbaikan, semua mukosa oral tampak erosi dangkal yang semakin meluas dan terdapat daerah yang ulseratif, lapisan pseudomembran yang semakin menebal, serta sloughing area di posterior gigi molar ketiga kanan-kiri bawah (gambar 2a,b,c). Berdasarkan gambaran klinis tersebut tampak peningkatan derajat keparahan mukositis oral, dapat disimpulkan pasien menderita mukositis oral derajat III. Pasien diinstruksikan untuk melanjutkan pemakaian obat dengan benar dan teratur.

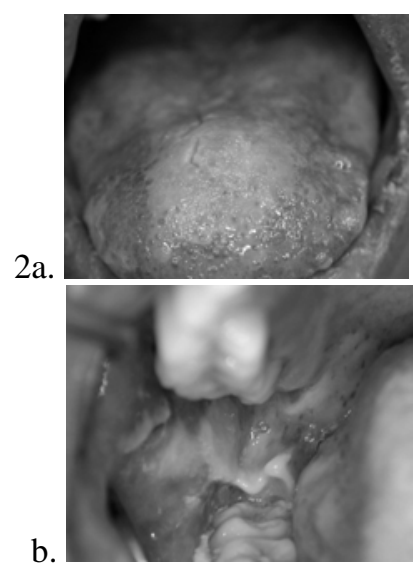


Faktor risiko mukositis oral

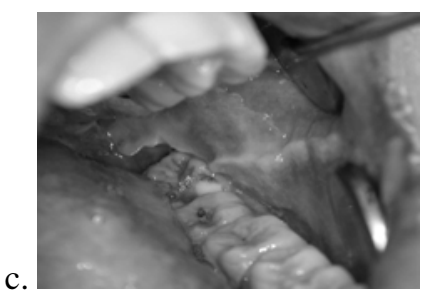

Gambar 2. Semua mukosa oral tampak erosi dangkal yang semakin meluas dan lapisan pseudomembran yang semakin menebal pada dorsum lidah (a) serta sloughing area di mukosa bukal terutama posterior gigi molar ketiga kanan-kiri bawah (b dan c)

Pada pemeriksaan tanggal 10 Oktober 2005 (11 hari kemudian) mukositis oral semakin parah. Tampak sloughing area pada dorsal, lateral, ventral lidah, dasar mulut, mukosa labial dan mukosa bukal kiri-kanan, serta perdarahan spontan pada ventral lidah. (gambar 3a,b,c). Berdasarkan gambaran klinis tersebut, tingkat keparahan mukositis oral meningkat menjadi derajat IV. Pasien tetap tidak teratur menggunakan obat terutama klorheksidin glukonat 0,2\% karena merasa perih. Pasien dianjurkan menggunakan Mycostatin dengan benar (3-5 menit) dan teratur, obat kumur diencerkan untuk mengurangi rasa perih.

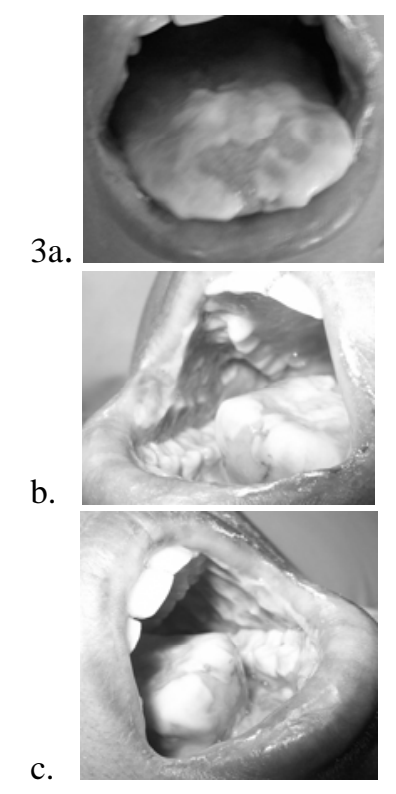

Gambar 3. Sloughing area pada lidah (a) dan mukosa bukal kanan-kiri (b dan c) semakin banyak, serta perdarahan spontan pada ventral lidah.
Pada pemeriksaan terakhir 19 Oktober 2005 (20 hari kemudian), tampak mukositis oral sudah mengalami perbaikan (gambar 4a,b,c). Tetapi pada lateral kanan-kiri lidah masih tampak lapisan putih kekuningan yang sulit diangkat. Pasien tetap diinstruksikan memakai obat yang sudah diberikan dengan benar dan teratur.

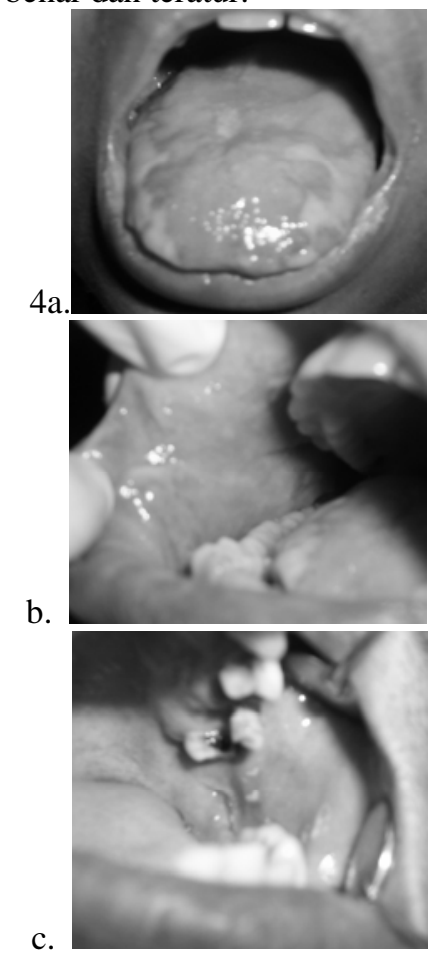

Gambar 4. Mukositis oral sudah mengalami perbaikan, hanya pada lateral kanan-kiri lidah masih tampak lapisan putih kekuningan yang sulit diangkat.

\section{Pembahasan}

Pada kasus ini, saat kunjungan pertama ditegakkan diagnosis mukositis oral derajat II disertai kandidiasis oral tetapi kemudian tingkat keparahannya meningkat hingga mencapai derajat IV. Penilaian tingkat keparahan mukositis oral tersebut sesuai skoring menurut WHO yaitu mukositis derajat II berupa eritema dan ulserasi di mukosa oral; sedangkan ulserasi dengan eritema yang meluas menunjukkan derajat III; dan mukositis yang meluas dimana pasien tidak dapat makan melalui mulut menunjukkan derajat IV. . $^{1-12,16,18}$ Sedangkan menurut NCI-CTC, adanya bercak ulserasi atau 
pseudomembran adalah gambaran mukositis derajat II; ulserasi atau pseudomembran yang bergabung, perdarahan pada trauma minor menunjukkan derajat III; adanya jaringan nekrosis dan perdarahan spontan adalah gambaran derajat IV. ${ }^{1-5,9}$

Kandidiasis oral ditegakkan berdasarkan gambaran klinis ditunjang oleh pemeriksaan mikologi langsung. Bercak-bercak putih yang dapat diangkat dengan dasar eritema pada lidah dan mukosa bukal menunjukkan kandidiasis pseudomembran, sedangkan sudut bibir yang pecah menggambarkan keilitis angularis. Literatur menyebutkan bahwa infeksi yang paling sering terjadi pada pasien yang menjalani radioterapi daerah kepala-leher adalah kandidosis, patogen yang paling sering yaitu Candida albicans, ${ }^{4,11,20,22}$ yang merupakan agen infeksi oportunistik sebab pada keadaan normal terdapat di dalam rongga mulut. ${ }^{4}$ Pasien dengan kerusakan mukosa oral dan imunitas yang menurun akibat radioterapi cenderung terjadi infeksi oportunistik di rongga mulutnya. ${ }^{11,21}$ Prevalensi kultur kandida positif meningkat 43\%-62\% pada terapi kanker dan sampai 75\% selama periode follow up. ${ }^{11}$

Pada kasus ini, berbagai faktor yang dapat meningkatkan kerentanan terhadap kandidosis oral adalah penurunan produksi saliva, perubahan epitel mukosa, defisiensi nutrisi, dan kesehatan mulut yang buruk. Saliva penting dalam mempertahankan mikroflora oral normal. Saliva mengencerkan antigen patogenik dan secara mekanis membersihkan mukosa. Antibodi saliva (SIg A) dan faktor-faktor antimikroba nonspesifik penting untuk menurunkan perlekatan dan kolonisasi fungal, ${ }^{23}$ oleh karena itu aliran/produksi saliva yang menurun akibat terapi radiasi memicu infeksi kandida pada pasien ini. Radiasi pada daerah kepala-leher dapat merubah kecepatan pergantian epitel normal, menyebabkan efek sitotoksik langsung yang dapat merubah integritas epitelium oral dan memicu infeksi sekunder pada pasien ini. Defisiensi nutrisi dapat menyebabkan penurunan daya tahan tubuh dan hilangnya integritas sel, yang akan mempermudah invasi dan infeksi kandida. ${ }^{23}$ Kebersihan mulut yang buruk membantu lingkungan yang konduktif dalam meningkatkan kolonisasi dan perlekatan kandida. ${ }^{23}$ Diyakini bahwa mukositis oral diperberat oleh infeksi fungal, ${ }^{11}$ dimana mikroorganisme oral berperan dalam memperberat kerusakan epitel (mukosa). ${ }^{19,22}$

Dari penelusuran beberapa literatur menunjukan bahwa insidensi dan keparahan mukositis oral berkaitan dengan berbagai faktor risiko yaitu yang berhubungan dengan pasien (usia, jenis kelamin, kesehatan mulut dan kebersihan mulut, faktor genetik, penurunan produksi saliva, status nutrisi yang buruk, fungsi ginjal dan fungsi hepatik, penyakit diabetes, infeksi Human Imunnodeficiency Virus, konsumsi alkohol, merokok, kelainan patologi oral atau vaskular sebelumnya, tipe kanker, disfungsi imun dan jumlah neutrofil, defek enzim metabolisme tertentu, kelainan pernafasan, gigi yang tajam); dan faktor risiko yang berhubungan dengan terapi kanker itu sendiri (agen kemoterapi atau bioterapi, transplantasi sel stem sumsum tulang dan darah, daerah radiasi dan fraksionasi, frekuensi dan dosis radiasi, volume jaringan yang diradiasi, medikasi lain [opioid, antidepresan, antihistamin, diuretik, sedatif], dan terapi oksigen). ${ }^{1-14,17,19}$ Sedangkan faktor risiko yang berperan terhadap keparahan mukositis oral pada kasus ini dapat diidentifikasi yaitu gender, kebersihan mulut yang buruk, penurunan produksi saliva, status nutrisi yang buruk, tipe/tahapan kanker yang sudah lanjut, daerah radiasi, dosis total terlalu tinggi serta hiperfraksionasi radiasi.

Sebuah literatur menyebutkan bahwa wanita mempunyai risiko lebih besar terjadinya mukositis oral yang parah dibanding pria, ${ }^{7}$ tetapi literatur lain menyatakan bahwa gender bukan merupakan faktor risiko karena tidak ada perbedaan antara pria dan wanita terhadap terjadinya mukositis oral yang parah. ${ }^{6,24}$ Peneliti dari Mayo Clinic and Mayo Foundation melaporkan bahwa pada wanita terjadi mukositis oral yang lebih parah dan lebih sering daripada pria, terutama jika menjalani kemoterapi dengan 5-FU, oleh karena itu diduga jenis kelamin perempuan dapat dimasukkan ke dalam salah satu faktor risiko mukositis oral. ${ }^{4,12}$ 
Status kebersihan mulut pasien ini juga berkontribusi untuk keparahan mukositis oral, sesuai literatur yang menyatakan bahwa kebersihan mulut yang buruk seringkali berhubungan dengan mukositis yang parah, ${ }^{1,2,5-}$ 7,9,13,17,19,25 dimana jaringan mukosa yang sensitif dapat terinfeksi dengan mudah oleh mikroorganisme, termasuk jamur, virus herpes dan bakteri. ${ }^{23}$

Pada pasien ini dijumpai saliva sedikit dan kental. Literatur menyebutkan sekresi saliva cenderung menurun secara drastis pada daerah yang terkena radiasi. $^{26}$ Sebuah penelitian menunjukkan bahwa penggunaan radioterapi dosis penuh yang melibatkan kelenjar saliva mayor untuk karsinoma sel skuamosa orofaring tahap lanjut menyebabkan hiposalivasi berat dengan perubahan $\mathrm{pH}$ saliva dan kapasitas buffer. ${ }^{26}$ Disfungsi kelenjar saliva merupakan komplikasi mayor jangka panjang setelah terapi kanker di daerah kepala-leher, terjadi secara progresif dikarenakan atrofi kelenjar yang kronis, kemudian berhubungan dengan kematian sel stem dan beberapa respon akibat radiasi dengan adanya stroma pada fibrovaskuler dan kerusakan vaskuler yang spesifik (endarteritis). ${ }^{26}$ Literatur lain menyebutkan mekanisme kerusakan kelenjar yang dipicu oleh radiasi belum diketahui dengan pasti, tetapi setidaknya ada tiga mekanisme yang diduga dapat menjelaskan fenomena tersebut. Pertama, kerusakan langsung pada DNA sel kelenjar saliva oleh proses oksidatif yang dipicu oleh radiasi. Kedua, kerusakan sitotoksik pada sel yang dipicu oleh pelepasan bahan toksik dari sel itu sendiri. Ketiga, induksi radiasi apoptosis oleh mekanisme intraselular. ${ }^{27}$

Status nutrisi pasien ini tampaknya buruk, dimana berat badan tidak sesuai dengan tinggi badan dan pasien terlihat kurus. Dari anamnesis dikatakan pasien mengalami penurunan berat badan yang drastis selama menderita KNF. Penderita kanker sering disertai kaheksia, yaitu suatu sindroma yang ditandai dengan gejala klinik berupa anoreksia, perubahan ambang rasa kecap, anemia, gangguan metabolisme karbohidrat, protein dan lemak, penurunan berat badan. Disamping itu, terapi kanker pada daerah kepala-leher juga dapat mempengaruhi status nutrisi. Keparahan malnutrisi ditentukan oleh tempat dilakukan radiasi, dosis dan lama radiasi. $^{28}$ Mukositis oral yang parah menyebabkan rasa sakit, mengurangi kemampuan pasien untuk mengunyah, menelan, dan berbicara, mengakibatkan malnutrisi, dehidrasi, anoreksia, kaheksia, sehingga pasien makan melalui selang nasogaster, ${ }^{11,12}$ seperti pada kasus ini. Malnutrisi sendiri dapat meningkatkan risiko keparahan mukositis, ${ }^{5-8,19}$ karena intake gula tinggi atau malnutrisi protein-kalori, sehingga menambah dehidrasi yang dapat mengiritasi mukosa dan meningkatkan kerusakan gigi serta penyembuhan mukosa oral yang lambat. ${ }^{8}$

Dari hasil biopsi disimpulkan pasien mengalami KNF jenis skuamosa derajat keganasan tinggi. Setelah dilakukan radiasi eksterna diketahui tahapan kanker pasien adalah TxN3M1. Keadaan ini mempengaruhi kondisi umum pasien, yang memudahkan perkembangan mukositis oral. Derajat keparahan dan durasi mukositis oral pada pasien ini juga dipengaruhi oleh sumber radiasi, dosis kumulatif, intensitas dosis, dan hiperfraksionasi (diberikan dosis 300 cGy pada setiap terapi, dimana umumnya hanya diberikan 200 cGy). Literatur menyebutkan bahwa pasien yang menerima terapi radiasi kepala-leher cenderung terjadi eritema selama 2 minggu terapi, dengan total dosis hampir mencapai $2.000 \mathrm{cGY}$, gejala mencapai puncaknya pada minggu kelima atau keenam dari terapi radiasi. Keparahan meningkat sesuai peningkatan dosis, reaksi mukosa terburuk pada dosis total 5.000-6.000 cGy. Sebuah penelitian meta-analisis menyatakan bahwa hiperfraksionasi mempengaruhi keparahan, sebanyak 56\% pasien yang mendapat terapi radiasi fraksionasi mempunyai mukositis derajat 3-4, dibandingkan dengan 34\% pasien yang mendapat terapi radiasi konvensional. ${ }^{4} \quad$ Fraksionasi yang dipercepat menghasilkan onset mukositis yang lebih cepat. ${ }^{11}$

Pengobatan berupa pemberian obat kumur klorheksidin glukonat $0,2 \%$ dengan cara diseka ke seluruh mukosa mulut dan gigi geligi, juga obat tetes Mycostatin oral supension (nistatin). Klorheksidin adalah obat kumur yang 
menunjukkan aktivitas antimikroba dan antijamur sprektrum luas, ${ }^{2,17}$ efektif melawan bakteri gram positif dan gram negatif, juga sel ragi dan jamur, ${ }^{17,29}$ dan terikat pada permukaan oral secara terus menerus. ${ }^{2}$ Hasil penelitian Rutkauskas dkk. menunjukkan pengurangan keparahan mukositis yang signifikan pada kelompok klorheksidin dibandingkan dengan kelompok placebo. ${ }^{2}$ Nistatin merupakan drug of choice untuk perawatan kandidosis oral yang terlokalisir. $^{30}$ Penelitian Carpentieri dkk. menunjukkan bahwa pemberian nistatin pada pasien yang menjalani kemoterapi dapat menurunkan insidensi mukositis. ${ }^{2}$ Pada kasus ini, pemberian nistatin tampak efektif setelah pemakaian botol kedua dan digunakan sesuai instruksi.

Akhirnya mukositis oral pada kasus ini menunjukkan penyembuhan yang baik seiring dengan selesainya terapi kanker dan pengobatan topikal intra oral yang diberikan, walaupun belum optimal. Hal ini dikarenakan beberapa faktor risiko yang tidak dapat dikendalikan, antara lain pasien tidak dapat dilakukan tindakan dental berupa eliminasi fokus infeksi.

\section{Kesimpulan}

Identifikasi dan pengendalian faktor risiko mukositis oral penting dilakukan pada penderita kanker nasofaring yang menjalani radioterapi, terutama sebelum terapi kanker dimulai untuk dilakukan tindakan profilaksis, dan perawatan segera terhadap mukositis oral dan infeksi yang menyertainya selama radioterapi akan mengurangi keparahannya, dengan demikian dapat meningkatkan kualitas hidup pasien lebih baik.

\section{Daftar Pustaka}

1. Naidu MUR, et al. Chemotherapy-Induced and/or Radiation Therapy-Induced Oral Mucositis-Complicating the Treatment of Cancer. Neoplasia 2004; 6(5):423-31.

2. Kostler WJ, et al. Oral Mucositis Complicating Chemotherapy and/or Radiotherapy: Options for
Prevention and Treatment. CA Cancer J Clin 2001; 51:290-315.

3. Alvarado Y, Bellm LA, Giles FJ. Oral Mucositis: Time for More Studies. Hematology 2002; 7(5):281-29.

4. Cawley MM, Benson LM. Current Trends in Managing Oral Mucositis. Clinical Journal of Oncology Nursing 2005; 9(5):584-92.

5. UNC Hospital, Nursing. Oral Mucositis. http://www.unchealthcare.org/site/Nursing/ nurspractice/protocols/protocols_pdf/protocolm 7.pdf. Revised 18 Oktober 2005. Diakses 19 Oktober 2005.

6. Oncology Nursing Society. Oral Mucositis. Definition and Description of Problem. http://onsoptent.ons.org/toolkits/evidence/Clinic al/pdf/Mucositis. Diakses 2 Januari 2006.

7. Avritscher EB, Cooksley CD, Elting LS. Scope \& Epidemiology of Cancer Therapy-induced Oral and Gastrointestinal Mucositis. Seminars in Oncol Nursing 2004;20(1):3-10.

8. Eilers J. Nursing Interventions and Supportive Care for the Prevention and Treatment of Oral Mucositis Associated With Cancer Treatment. Oncology Nursing Forum 2004; 31(4):13-23.

9. Dodd MJ. The Pathogenesis and Characterization of Oral Mucositis Associated With Cancer Therapy. Oncology Nursing Forum 2004; 31(4):5-11.

10. Stokman MA, et al. Oral Mucositis and Selective Elimination of Oral Flora in Head and Neck Cncer Patients Receiving Radiotherapy: A Double-blind Randomised Clinical Trial. British Journal Cancer 2003; 88:1012-6.

11. European Association of Oral Medicine. Mucositis. http://EAOM.. Diakses 21 Oktober 2005.

12. Maxon J. Advanced in the Prevention and Management of Oral Mucositis. Current Topics In Oncology. http://professional.cancerconsult ants.com/ current_oncology. Last update January 2005. Diakses tanggal 6 Januari 2006.

13. Dood MJ, et al. Factors Influencing Oral Mucositis in Patients Receiving Chemotherapy. Cancer Practice 2000; 8(6):291-7.

14. MGI Pharma. Manage Mucositis. About Oral Mucositis. http://www.managemucositis.com. Diakses tgl 1 Januari 2006. The Joanna Briggs Institute. Prevention and Treatment of Oral Muc ositis In Cancer Patients. Best Practice 1998; 2(3):1-6. 
15. Hsiao G, Sonis S. Oral Mucositis in Interactive Textbook on Clinical Symptom Research.. http://symptomresearch.nih.gov/Chapter_17.htm . Diakses tanggal 1 Januari 2006.

16. National Cancer Institute. Oral Complications of Chemotherapy and Head/Neck Radiation. http://www.nci. Last modified 18 Nov 2005. Diakses 6 Januari 2006.

17. AMGEN. About Oral Mucositis. http://www. kepivance.com/oral_mucositis. Diakses 1Januari 2006.

18. Cancer Symptom.org. Mucositis. Factors Affecting Mucositis. About Oral Mucositis. http://www.cancersymptom.org/mucositis/factor s.shtml. Diakses tgl 23 Maret 2006.

19. Rosenbau EH, et al. Mucositis-Oral Problems and solutions. Available at http://www.cancersu pportivecare.com/oral.php. Diakses 1 Februari 2006.

20. Belazi M, et al. Oral Candida Isolates in Patients Undergoing Radiotherapy for Head and Neck Cancer: Prevalence, Azole Susceptibility Profiles and Response to Antifungal Treatment. Oral Microbiology Immunology 2004; 19: 34751.

21. Hancock PJ, Epstein JB, Sadler1 GR. Oral and Dental Management Related to Radiation Therapy for Head and Neck Cancer. J Can Dent Assoc 2003; 69(9):585-90.

22. Sherman RG, Prusinski L, Ravenel MC, Joralmon RA. Oral Candidosis. Quintessence Int 2002;33:521-32.
23. Barasch A, Peterson DE. Risk Factors for Ulcerative Oral Mucositis in Cancer Patients: Unanswered Questions. Oral Oncol 2003; 39(2):91-100.

24. Luo DH, Hong MH, Guo KJ, Deng MQ, Mo HY. Analysis of Oral Mucositis Risk Factors during Radiotherapy for Nasopharyngeal Carcinoma Patients and Establishment of a discriminant model. Zheng Ai 2005;24(7):850-4.

25. Moller P, Perrier M, Ozsahin M, Monnier P. A Prospective Study of Salivary Gland Function in Patients Undergoing Radiotherapy for Squamous Cell Carcinoma of the Oropharynx. Oral Surg Oral Med Oral Pathol Oral Radiol Endod 2004; 97:137-89.

26. Berk LB, Shivnani AT, Smali W. Pathophysiology and Management of Radiationinduced Xerostomia. J Support Oncol 2005;3(3):191-200.

27. Quade D. Nutrition in Cancer Care. The National Cancer Institute. http://imsdd.meb.unibonn.de/cancer.gov/html. Last modified on Sonntag, 5 Feb 2006. Diakses 21 Feb 2006.

28. Shih A, Miaskowski, Dood MJ, Sotts NA, MacPhail L. A Research Review of the Current Treatments for Radiation-Induced Oral Mucositis in Patients With Head and Neck Cancer. SHIH 2002; 29 (7):1063-78.

29. Epstein JB, Gorsky M, Caldwell J. Fluconazole mouthrinses for Oral Candidiasis in Postirradiation, Transplant, and Other Patients. Oral Surg Oral Med Oral Pathol Oral Radiol Endod 2002; 93:671-5. 